$$
\text { DOE/CH/10324-TII }
$$

\title{
Southern States'
}

\section{Routing Agency Report}

Southern States Energy Board 3091 Governors Lakes Drive Suite 400 Norcross, Georgia 30071 (404) 242-7712

March 1990 


\title{
Southern States'
}

\section{Routing Agency Report}

\section{Prepared for U.S. Department of Energy under Cooperative Agreement DE-FCO22-87CH10324}

by the

\author{
Southern States Energy Board \\ 3091 Governors Lakes Drive \\ Suite 400 \\ Norcross, Georgia 30071 \\ (404) 242-7712
}

\section{March 1990 \\ DISCLAIMER}

This report was prepared as an account of work sponsored by an agency of the United States Government. Neither the United States Government nor any agency thereof, nor any of their employees, makes any warranty, express or implied, or assumes any legal liability or responsibility for the accuracy, completeness, or usefulness of any information, apparatus, product, or process disclosed, or represents that its use would not infringe privately owned rights. Referprocess disclosed, or represents that if product, process, or service by trade name, trademark, manufacturer, or otherwise does not necessarily constitute or imply its endorsement, recommendation, or favoring by the United States Government or any agency thereof. The views and opinions of authors expressed herein do not necessarily state or reflect those of the United States Government or any agency thereof. 


\section{TABLE OF CONTENTS}

Page

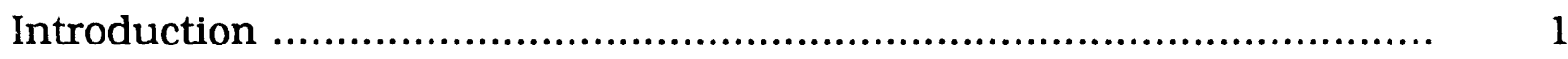

State Authority to Designate Preferred Routes (The HM-164 Process) .... $\quad 1$

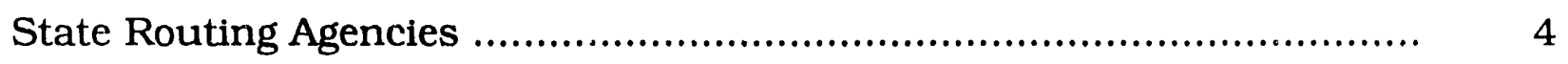

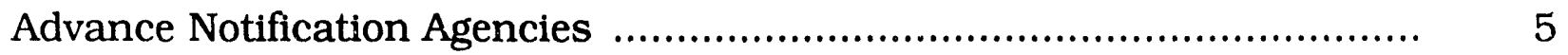

State-By-State Routing and Advance Notification Agencies $\ldots \ldots \ldots \ldots \ldots \ldots \ldots . \ldots$

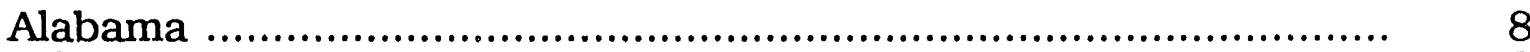

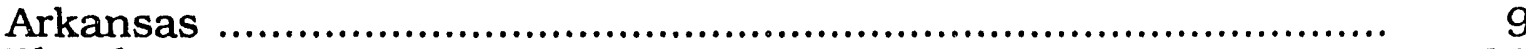

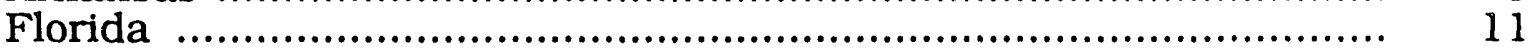

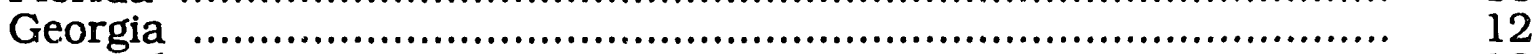

Kentucky ....................................................................................... 13

Louisiana ............................................................................. 14

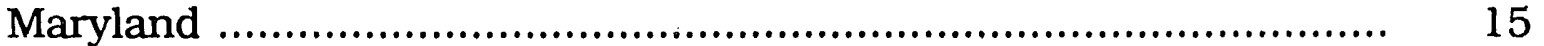

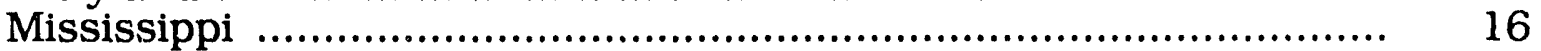

Missouri ...................................................................................... 17

North Carolina

Oklahoma …......................................................................... 19

South Carolina ....................................................................... 20

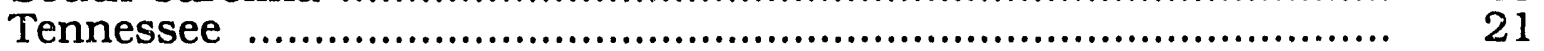

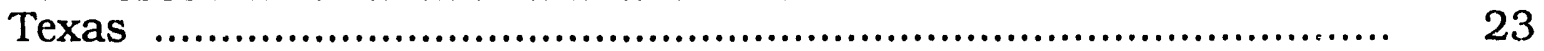

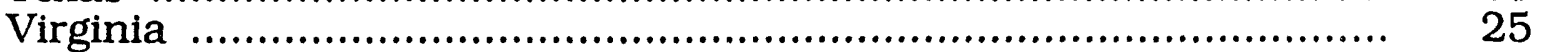

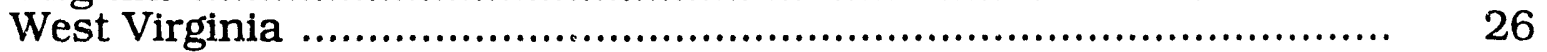

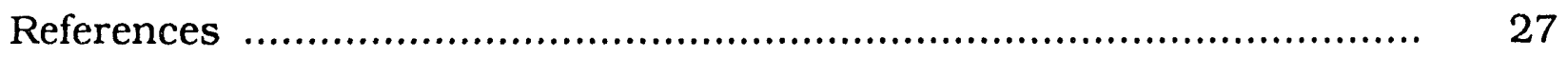




\section{INTRODUCTION}

The Southern States' Routing Agency Report is a compendium of 16-southern states' routing programs for the transportation of high-level radioactive materials. The report identifies the state-designated routing agencies as defined under 49 Code of Federal Regulations (CFR) Part 171 and provides a reference to the source and scope of the agencies' rulemaking authority. Additionally, the state agency and contact designated by the state's governor to receive advance notification and shipment routing information under $10 \mathrm{CFR}$ Parts 71 and 73 are also listed.

\section{STATE AUTHORITY TO DESIGNATE PREFERRED ROUTES (THE HM-164 PROCESS)}

Pursuant to the rulemaking authority granted under the Hazardous Materials Transportation Act (HMTA), the Department of Transportation (DOT) has promulgated a comprehensive set of regulations, commonly referred to by its rulemaking docket numbers HM-164 and 164A, concerning the highway routing of nuclear materials. Under these regulations, carriers of highway route-controlled quantities of nuclear material are required to use preferred routes, defined as interstate system highways or state-designated alternatives that provide an equal or greater level of safety (49 CFR 177.825).

In order to develop a system of state designated alternative routes, the state must designate a 'state routing agency,' defined as an entity authorized to use the state legal process to impose routing requirements on carriers of radioactive material (49 CFR 171.8). From a procedural standpoint, the state routing agency must select routes in accordance with DOT's Guidelines for Selecting Preferred Highway Routes for Large Quantity Shipments of Radioactive Materials or an equivalent analysis. This publication provides guidance to the states concerning comparative radiological risk assessment, local considerations and the impact and continuity of routes between adjoining states. DOT's regulations also require states to provide written notice to DOT of all state-designated alternative routes for the purpose of creating a central repository of such information. A state-designated route is not effective until notice is received. If a state fails to designate a system of state preferred routes, the interstate highways within the state will be deemed acceptable routes for the transportation of radioactive materials. The HMTA prohibits and preempts any state or local 
requirements that are inconsistent with the act or its implementing regulations. The federal consistency of a state or local regulation can be ascertained by requesting an advisory inconsistency ruling from DOT.

Accompanying 49 CFR Part 177 is a policy statement appendix that identifies those areas of state and local regulation that DOT deems inconsistent with federal regulations. This appendix provides that a state or local transportation rule is inconsistent with Part 177 if it:

(1) conflicts with [NRC] physical security requirements;

(2) requires additional or special personnel, equipment or escort;

(3) requires additional or different shipping paper entries, placards or other hazard warning devices;

(4) requires filing route plans or other documents containing information specific to individual shipments;

(5) requires prenotification;

(6) requires accident or incident reporting other than that immediately necessary for emergency assistance; or

(7) unnecessarily delays transportation (Sec. 46 Fed. Reg. supra note 21 , at 5,317$)$.

The validity of the DOT routing regulations has been upheld against state challenge (See New York City $v$. United States Department of Transportation. 715 F.2d 732 (2d Cir. 1983), cert. denied, 465 U.S. 1055 (1984).

While DOT's policy statement is advisory and does not have the force and effect of law, it provides important guidance on patterns of DOOT rulings and inconsistency proceedings. The courts have shown substantial de ference to DOT's views on shipments of radioactive materials.

If a state or local requirement is found by DOT to be inconsistent with the HMTA or the implementing regulations under HMTA Section 112(a), such a finding provides the basis for application to DOT for a discretionary waiver of preemption under HMTA Section 112(b). In this regard, HMTA Section 112(b) requires a waiver applicant to demonstrate the following: 
(1) that the preempted state or local requirement affords an equal or greater level of protection to the public as compared with the federal standards; and

(2) that is does not unreasonably burden commerce (See 49 CFR 107.215(b)(6), (7) (1986)).

Although states have the option to designate alternative preferred routes, federal hazardous material transportation regulations generally preempt state and local regulations on the same matter. This reflects the DOT's view that hazardous material transportation safety can be better achieved through a uniform system of regulation rather than through a collection of varied and/or inconsistent state and local regulations.

Despite federal preemption in this area, the states may develop their own system of preferred routes for the transportation of radioactive materials. Local governments, on the other hand, have not been encouraged to do the same owing to the belief that state governments are in a better position to perceive the overall objectives of a uniform national highway routing system. However, local officials have been encouraged to establish advisory organizations to present local views to state officials. 


\section{STATE ROUTING AGENCIES}

According to 49 CFR 171.8, a state routing agency is an entity that is authorized to use the state legal process to impose routing requirements, enforceable by state agencies, on carriers of radioactive materials. Consequently, the selection, establishment and authority of a state routing agency is determined by state legislative action and/or executive branch decision. In most southern states the legislature has enacted measures that identify and require a specific state agency to promulgate regulations, rules and policies regarding the transportation of radioactive material into, within or through the state. The state agencies may be required to develop regulations for a variety of transportation issues including routing, hazardous materials definitions, permits, advance notification, escorts and bonding requirements among others.

Several state statutes contain general grants of rulemaking authority over the transportation of hazardous materials including radioactive materials. There is some question whether a general grant of authority is sufficient to place the subject agency within the federal definition of a state routing agency. The failure to meet the federal definition could conceivably make any route selected by that agency invalid as a state alternative preferred route. Even if a statute is drafted in a manner which places the agency within the federal definition, the agency's failure to adhere to procedures developed for the selection of alternative preferred routes could expose the route designation to legal challenge. 


\section{ADVANCE NOTIFICATION AGENCIES}

The U.S. Nuclear Regulatory Commission (NRC) requires advance notification to governors or their designees concerning the transport of high-level radioactive materials and spent fuel shipments. The prenotification for spent nuclear reactor fuel shipments is addressed in 10 CFR Part 73 and the advance notification of large quantity radioactive waste shipments in 10 CFR Part 71 . In the South, all governors have designated a state agency and contact for receiving prenotification information. The state contact listing is updated annually in the Federal Register on or about June 30 .

The state agencies responsible for routing and advance notification in the South fall into seven general departmental categories including health, public safety, transportation, public service, state police/highway patrol, emergency management and nuclear waste. Only in Texas is the prenotification for spent fuel and large quantity shipments divided between two separate agencies. The following table indicates the state departmental authorities for routing and advance notification. 
Primary Southern State Departments Responsible for Radioactive Material Routing and Advance Notification

State

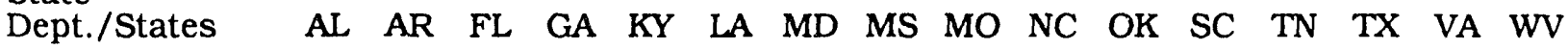

\begin{tabular}{|l|l|l|l|l|l|l|l|l|l|l|l|l|l|l|l|l|}
\hline Health & $\mathrm{R}$ & $\mathrm{N}$ & $\begin{array}{c}\mathrm{R} / \\
\mathrm{N}\end{array}$ & & $\mathrm{N}$ & & & & & & & $\begin{array}{c}\mathrm{R} / \\
\mathrm{N}\end{array}$ & & $\begin{array}{c}\mathrm{R} / \\
\mathrm{N}^{*}\end{array}$ & \\
\hline Public Safety & $\mathrm{N}$ & & & & & & & & $\mathrm{R}$ & & $\begin{array}{c}\mathrm{R} / \\
\mathrm{N}\end{array}$ & & & $\mathrm{N}^{* *}$ & & $\mathrm{~N}$ \\
\hline Transportation & & & & & $\mathrm{R}$ & & & $\mathrm{R}$ & & & & & & & & \\
\hline $\begin{array}{l}\text { Public Service } \\
\text { Commission }\end{array}$ \\
\hline $\begin{array}{l}\text { State Police/ } \\
\text { Highway Patrol }\end{array}$
\end{tabular}

$\mathrm{R}$ - Routing Department

$\mathrm{N}$ - Prenotification Department

Source: Federal Register, Vol. 53 No. 126, June 30, 1988, p.24818.

* large quantity shipments

** spent fuel 
STATE-BY-STATE ROUTING

AND ADVANCE NOTIFICATION AGENCIES AND CONTACTS 


\begin{abstract}
Alabama
State Routing Contact: Aubrey Godwin

Director

Radiological Health Branch

Alabama State Board of Health

434 Monroe Street, Room 510

Montgomery, Alabama 36130-1701

(205) 261-5315
\end{abstract}

Under Ala. Code \$22-14-1, the Alabama Board of Health has been designated as the state radiation control agency and empowered to promulgate rules regulating by-product, source and special nuclear materials. This statute covers a number of transportation related issues including permit fees, materials licensing and operator training. However, the statute does not contain a direct grant of authority to promulgate rules governing the routing of radioactive materials shipments. Since the Board of Health is not directly authorized to impose routing requirements on carriers of radioactive materials, it may not meet the CFR definition of a state routing agency.

As a practical matter, issues relating to routing are addressed by the Board of Health in consultation with other state agencies. Therefore, the board is listed above as the state routing agency.

The state agency designated by the governor to receive advance notification and shipment routing information under 10 CFR Parts 71 and 73 is the Alabama Department of Public Safety. The contact to receive advance notification for spent fuel and large quantity radioactive waste shipments is listed below.

Advance Notification Contact: Col. Thomas H. Wells

Director

Alabama Department of Public Safety

P.O. Box 1511

Montgomery, Alabama 36192

(205) 261-4378 


\section{Arkansas}

State Routing Conact: Capt. Larry Fletcher

Arkansas State Police

P.O. Box 5901

Number 3

Natural Resources Drive

Little Rock, Arkansas 72115

(501) 224-2882

There is no state agency, under Arkansas statutory law, directly vested with authority to impose routing requirements on carriers of radioactive materials pursuant to 49 CFR 171.8. Under Ark. Code Ann. 23-2-204, the Arkansas Transportation Safety Agency assumed those powers granted to its predecessor agency. The Transportation Safety Agency, however, was abolished in 1989, and no replacement has been named.

The Arkansas Hazardous Waste Management Act of 1979, Ark. Code Ann. \$8-7-201, authorizes the Arkansas Department of Pollution Control and Ecology to promulgate and enforce all rules and regulations relating to the transportation of hazardous waste. The act defines hazardous waste as any waste or combination of wastes including radioactive wastes which may cause, among other things, a substantial hazard to human health. While this statute does not directly mention the routing of radioactive materials, the act does grant authority to promulgate rules relating to the transportation of radioactive material. Consequently, the Department of Pollution Control and Ecology could be construed as the state routing agency based on a broad interpretation of the federal definition in 49 CFR 171.8 .

The governor has selected the Arkansas Department of Health's Division of Radiation Control and Emergency Management to receive shipment notification and routing information according to $10 \mathrm{CFR}$ Parts 71 and 73 . The contact to receive advance notification for spent fuel and large quantity radioactive waste shipments is listed below. 
Advance Notification Conact: Greta J. Dicus

Director

Division of Radiation Control and

Emergency Management Programs

Arkansas Department of Health

4815 West Markham Street

Little Rock, Arkansas 72201

(501) 662-2301

After hours: (501) 661-2136 or 661-2000 


\section{Florida}

State Routing Contact: Dan Thoss

Public Health Physicist

Florida Department of Health and

Rehabilitative Services

P.O. Box 15490

Orlando, Florida 32858

(407) 297-2095

The Florida Radiation Protection Act, Fla. Stat. Arin. § 404.011, establishes the Department of Health and Rehabilitative Services as the authoritative state routing agency. The department is mandated to adopt reasonable rules governing the transportation of radioactive materials including criteria for departmental approval and designation of routes within the state. Fla. Stat. Ann. $\$ 404.20$ (1)(a). In addition, the act provides that rules adopted by the department may also be enforced within their respective jurisdictions by the Department of Highway Safety and Motor Vehicles and the Department of Transportation.

The state agency designated by the governor to receive advance notification and shipment routing information according to 10 CFR Parts 71 and 73 is the same as the state routing agency. The contact to receive advance notification within the Department of Health and Rehabilitative Services' Office of Radiation Control is listed below.

Advance Notification Contact: Harlan Keaton

Public Health Physicist Manager

Office of Radiation Control

Florida Department of Health and

Rehabilitative Services

P.O. Box 15490

Orlando, Florida 32858

(407) 297-2095 


\section{Georgia}

State Routing Contact: Lucia Ramey

Director of Compliance and Safety

Transportation Division

Georgia Public Service Commission

1007 Virginia Avenue, Suite 310

Hapeville, Georgia 30354

(404) 559-6602

Under the Transportation of Hazardous Materials Act, Ga. Code Ann. 46-11-1, the Georgia Public Service Commission is given authority to promulgate transportation regulations and permit requirements consistent with the federal rules. This legislation allows the commission to make changes in shipper-proposed routes as a precondition to the grant of a transportation permit. Consequently, the act establishes the Public Service Commission as the routing agency under federal rules.

According to the Georgia Public Service Commission, all spent fuel and large quantity shipments have taken place on federal interstate highways. The commission has, therefore, not moved to develop any alternate preferred highway routes. On issues concerning truck weight, length and width, the commission defers to the Department of Transportation.

The governor has designated the Public Service Commission as the agency to receive advance notification and shipment routing information under $10 \mathrm{CFR}$ Parts 71 and 73. The contact to receive advance notification for spent fuel and large quantity radioactive waste shipments is listed below.

Advance Notification Contact: Tom Doyal

Director

Transportation Division

Georgia Public Service Commission

1007 Virginia Avenue

Hapeville, Georgia 30354

(404) 559-6600 


\section{Kentucky}

State Routing Contact: Milo D. Bryant

Secretary \& Commissioner

of Highways

Transportation Cabinet

State Office Building, 10th Floor

Frankfort, Kentucky 40622

(502) $564-4890$

Kentucky has adopted legislation relating to the transportation of hazardous material including radioactive waste. Under Ky. Rev. Stat. Ann. \$174.410, the Secretary of the Transportation Cabinet is responsible for regulating the movement of all radioactive materials transported by all carrier modes within the state in a manner consistent with the federal regulations. This legislation does not contain a specific grant of authority to impose routing restrictions on carrier. However, the statute's general grant of authority to control the movement of all radioactive materials may be sufficient to place the Transportation Cabinet within the federal definition of a state routing agency.

The governor has designated the Radiation Control office in the Department for Health Services as the agency to receive advance notification and shipment routing information under $10 \mathrm{CFR}$ Parts 71 and 73 . The contact to accept advance notification for spent fuel and large quantity radioactive waste shipments is listed below.

Advance Notification Contact: Donald R. Hughes

Manager

Radiation Control

Department for Health Services

275 East Main Street

Frankfort, Kentucky 40621

(502) 564-3700 


\section{Louisiana}

State Routing Contact: Dr. L. Hall Bohlinger

Manager

Licensing and Registration Section

Nuclear Energy Division

Office of Air Quality and Nuclear Energy

Department of Environmental Quality

P.O. Box 14690

Baton Rouge, Louisiana 70898-4690

(504) 9259518

The Louisiana Nuclear Energy and Radiation Control Law, La. Rev. Stat. Ann. §30:1101, was enacted to ensure the safety environmental resources of Louisiana by providing an efficient system to regulate and control all sources of radiation within the state. To that end, La. Rev. Stat. \$30:1111 provides that the Secretary of Environmental Quality may promulgate rules, including route designations, governing the transportation of radioactive materials. Consequently, the Department of Environmental Quality is vested with authority to impose routes on carriers pursuant to 49 CFR 171.8 .

Additionally, La. Rev. State Ann. §30:1111(G) provides that regulations adopted by the secretary may be enforced by other state agencies according to mutual understandings between such agencies. Consequently, the actual implementation and enforcement is performed by the state police.

The governor chose the state police as the state agency to receive advance notification and shipment routing information under 10 CFR Parts 71 and 73. The contact for advance notification for spent fuel and large quantity radioactive waste shipments is the same as listed below.

Advance Notification Contact: Capt. William Spencer

Louisiana State Police

7901 Independence Blvd.

P.O. Box 66614

Baton Rouge, Louisiana 70896

(504) 925-6613 


\section{Maryland}

Maryland law is silent regarding the establishment of a state routing agency. However, activities relating to the routing of radioactive waste shipments including the development of a comprehensive routing plan - have been addressed by a core group of state agencies composed of the Department of Transportation. State Police and the Department of the Environment.

The Maryland State Police is the governor's designated agency to receive advance notification and shipment routing information under 10 CFR Parts 71 and 73. The contact to receive advance notification for spent fuel and large quantity radioactive waste shipments is listed below.

Advance Notification Contact: Col. James A. Jones

Chief

Service Bureau

Maryland State Police

1201 Reisterstown Road

Pikesville, Maryland 21208

(301) 486-3101 


\section{Mississippi}

State Routing Contact: Robert L. Hollimon

Mississippi Highway Department

P.O. Box 1850

Jackson, Mississippi 39215

(601) 359-1213

The Mississippi Radiation Protection Law of 1976 authorizes the State Board of Health to promulgate regulations governing the transportation of radioactive materials in the state, including the designation of state routes. Therefore, the Board is the official state routing agency as defined under 49 CFR 170.8 .

Under Miss. Code Ann. 45-14-25(2)(a), regulations adopted by the agency may be enforced, within their respective jurisdictions, by other state agencies, according to mutual understandings between such agencies. Consequently, actual authority over the routing of shipments is exercised by the Highway Department.

The governor has also formally designated the Emergency Management Agency as the department to receive advance notification and shipment routing information under $10 \mathrm{CFR}$ Parts 71 and 73 . The contact to obtain advance notification for spent fuel and large quantity radioactive waste shipments is listed below.

Advance Notification Contact: James E. Maher

Director

Mississippi Emergency Management Agency

P.O. Box 4501

Fondren Station

Jackson, Mississippi 39216

(601) 352-9100 


\section{Missouri}

State Routing Contact: Mr. Richard C. Rice

Director

Department of Public Safety

Truman Building, Box 749

Jefferson City, Missouri 65102

(314) 751-4905

There has been no statutory enactment vesting any division of state government with power to adopt regulations governing the routing of radioactive materials. Shippers of high-level waste must adhere to the applicable federal regulations.

The governor has designated the Emergency Management Agency as the department to receive advance notification and shipment routing information under 10 CFR Parts 71 and 73. The agency contact for advance notification for spent fuel and large quantity radioactive waste shipments is listed below.

Advance Notification Contact: Richard D. Ross

Director

State Emergency Management Agency

1717 Industrial Drive

P.O. Box 116

Jefferson City, Missouri 65102

(314) 751-9779

After hours: (314) 751-2748 


\section{North Carolina}

State Routing Contact: Dayne Brown

Chief

Radiation Protection Section

Division of Facility Services

North Carolina Department of Human Resources

701 Barbour Drive

Raleigh, North Carolina 27603-2008

(919) 733-4283

Under the North Carolina Radiation Protection Act, N.C. Gen. Stat. Ch. 104 $\mathrm{E}-1$, the Department of Human Resources is designated as the state agency to administer the statewide radiation protection program. The act also created the North Carolina Radiation Protection Commission, which is authorized to promulgate rules and regulations relating to the transportation of radioactive materials, including designation of routes which are to used for the transportation of radioactive materials (N.C. Ga. Stat. 104 E-15).

The state agency selected by the governor to receive advance notification and shipment routing information under 10 CFR Parts 71 and 73 is the North Carolina Highway Patrol. The contact to receive advance notification for spent fuel and large quantity radioactive waste shipments is listed below.

Advance Notification Contact: Major Walter K. Chapman

Director

Administrative Services

North Carolina Highway Patrol Headquarters

P.O. Box 27687

Raleigh, North Carolina 27611

(919) 733-7952

After hours: (919) 733-3861 


\section{Oklahoma}

State Routing Contact: 1LT Garry Thomas

Oklahoma Department of Public Safety

Highway Patrol Division, Troop S

3600 N. King Avenue

P.O. Box 11415

Oklahoma City, Oklahoma 73136-0145

(405) 521-6104

The Oklahoma Motor Carrier Safety and Hazardous Materials Transportation Act, Okla. Stat. Ann. 47 \$230.1, authorizes the Department of Public Safety to promulgate regulations relative to motor carrier safety in the transportation of hazardous materials. Hazardous material is broadly defined as a substance or material capable of posing an unreasonable risk when transported in commerce. The statute lacks any specific reference to the agency's authority to impose routing restrictions and, therefore, may not be sufficient to place the department within the federal definition of a state routing agency.

The Oklahoma Highway Patrol's Size and Weight's Section (Troop S) of the Oklahoma Department of Public Safety is the responsible state routing agency for high-level radioactive materials. The agency's authority involves strictly routing and does not include specific responsibility for hazardous materials. Instead, the agency relies on the technical support of several other agencies, including the Department of Public Safety's Hazardous Materials Section, the Department of Transportation, the Health Department and the State Civil Defense Agency.

There is no specific state or local legislation that affects the routing of radioactive materials. The state follows federal routing guidelines.

The Oklahoma Department of Public Safety is also the governor's designated state agency tc receive advance notification and shipment routing information under 10 CFR Parts 71 and 73. The contact for advance notification for spent fuel and large quantity radioactive waste shipments is the state Highway Patrol's representative listed above. 


\title{
South Carolina
}

\author{
State Routing Contact: Heyward Shealy \\ Chief \\ Bureau of Radiological Health \\ South Carolina Department of Health \\ and Environmental Control \\ 2600 Bull Street \\ Columbia, South Carolina 29201 \\ (803) 253-4634
}

According to the South Carolina Radioactive Waste Transportation and Disposal Act of 1976, S.C. Code Ann. \$13-7-110, the Department of Health and Environmental Control has regulatory authority over high-level radioactive waste transportation into or within the state, including the authority to impose routing requirements on carriers. Therefore, the act establishes the department as the official routing agency under the federal rules. The legislation also requires shippers to comply with all applicable state and federal laws, rules and regulations, hold the state harmless for any radiological claims, purchase a permit for transport through the state and provide the state with advance notification of shipments.

The Department of Health and Environmental Control may call upon the Highway Department and Governor's Office to provide technical transportation and routing support.

The state agency selected by the governor to receive advance notification and shipment routing information under 10 CFR Parts 71 and 73 is the South Carolina Department of Health and Environmental Control. The contact for advance notification for spent fuel and large quantity radioactive waste shipments is the same as listed above. 


\title{
Tennessee
}

\author{
State Routing Contact: Paul Melander \\ Tennessee Public Service Commission \\ 460 James Robertson Parkway \\ Nashville, Tennessee 37243-0505 \\ (615) 741-0484
}

Tennessee has enacted legislation regarding the transportation of spent nuclear fuel. Tenn. Code Ann. \$65-15-126 requires transporters of spent nuclear fuel to provide advance notice to the Tennessee Emergency Management Aigency which in turn shall notify the Tennessee Public Service Commission. The act defines spent nuclear fuel in accordance with the definition found in 42 U.S.C. \$10101(12) and (23). The act assess a fee for any shipments received at, or departing from, any nuclear power station or reactor spent fuel storage facility located within the state. Fees also are assessed for any shipments that pass through the state. Fees are set at $\$ 1,000.00$ per cask for truck shipment and $\$ 2,000.00$ per cask for rail shipments. A bond or surety must be provided in advance of shipment, to guarantee payment of the fees. Both the shipping fees and the surety bond are paid by the owner of the facility except when the shipment is passing through the state, in which case the shipper is responsible for payment of the surety bond and fees. All fees are collected by the commission and are deposited into the state general fund.

The act requires an escort for all shipments that pass within or through the state. Any training, manpower and equipment necessary for the escort service shall be in accordance with standards established by the commission.

Finally, the act authorizes the commission to adopt further regulations concerning the transportation of spent nuclear fuel as long as such regulations are not more restrictive than those adopted by the NRC or DOT.

The act is silent regarding the authority to impose routing requirements on carriers. Consequently, the commission does not meet the federal definition of a state routing agency. Despite the lack of direct statutory authority, however, the commission is the state agency most actively involved in the routing of radioactive materials and, therefore, it is at least de facto routing agency.

The state designee to receive advance notification and shipment routing information under $10 \mathrm{CFR}$ Parts 71 and 73 is the Tennessee Emergency Management Agency. The contact to be informed in advance of spent fuel and large quantity radioactive waste shipments is provided below. 
Advance Notification Contact: John White

Assistant Deputy Director

Tennessee Emergency Management Agency

State Emergency Operations Center 3041 Sidco Drive

Nashville, Tennessee 37204

(615) 252-3300

After hours: $1-800-258-3300$ 


\section{Texas}

State Routing Contact: David Lacker

Chief

Bureau of Radiation Control

Texas Department of Health

1100 W. 49th Street

Austin, Texas 78756-3189

(512) 835-7000

Under the Texas radiation control statute, the Department of Health is designated as the Texas Radiation Control Agency. The act further provides that the Commissioner of the Department of Health is required to designate an individual to be director of the Radiation Control Program. Tex. Rev. Civil Stat. Art. 4590F $\S 4(\mathrm{a})$,(b). This legislation also authorizes the agency to formulate rules and guidelines providing for the transportation and routing of radioactive material within the state. Tex. Rev. Civil Stai. Art. 4590F \&4 (d), (9c). Therefore, this statute establishes the department as the authoritative routing agency for the purposes of the federal rules.

Unlike other southern states, the governor has selected two separate agencies to receive advance notification and shipment routing information for large quantity and spent fuel shipments. The state agency to receive advance notification and shipment routing information for large quantity shipments under 10 CFR Part 71 is the Texas Department of Health. Bureau of Radiological Health. The Texas Department of Public Safety, meanwhile, is the state agency to receive advance notification and shipment routing information for spent fuel shipments under 10 CFR Part 73. The contacts to receive their respective advance notification and shipment routing information are listed below. 
Advance Notification Contact: Dr. Robert Bernstein

(10 CFR Part 71)

Commissioner

Texas Department of Health

1100 West 49 th Street

Austin, Texas 78756

(512) 458-7375

Advance Notification Contact: Col. Leo Gossett

(10 CFR Part 73)

Director

Texas Department of Public Safety

5805 N. Lamar Blvd.

Austin, Texas 78752

(512) 465-2000 


\section{Virginia}

State Routing Contact: James Holloway

Chief

Technological Hazards Branch

Virginia Department of Emergency Services

310 Turner Road

Richmond, Virginia 23225

(804) 674-2400

Virginia statutory law relative to the transportation of radioactive materials contains no grant of authority sufficient to place any state agency within the federal definition of a state routing agency found in 49 CFR 171.825.

Va. Code Ann. § 44-146.30 requires the Coordinator of the Department of Emergency Services to maintain a register of shippers and monitor the transportation of hazardous radioactive materials. The authority to maintain a list of shippers and monitor the transportation of radioactive materials does not constitute the authority to impose routing requirements on carriers necessary to comply with the federal definition of a routing agency.

As a practical matter, information and activities relating to the transportation of radioactive materials, such as notification of proposed routes, material shipped, transportation mode and shipment schedule, are handled by the Department of Emergency Services. Consequently, the department listed above is the state routing agency.

The state agency receiving advance notification and shipment routing information under 10 CFR Parts 71 and 73 is the Virginia Department of Emergency Services. The contact to accept advance notification for spent fuel and large quantity radioactive waste shipments is listed below.

Advance Notification Contact: Michael M. Cline

Director of Operations

Virginia Department of Emergency Services

310 Turner Road

Richmond, Virginia 23225

(804) 674-2400 


\section{West Virginia}

There has been no formal executive or legislative action giving any state agency rulemaking authority over routing of radioactive waste shipments. Transporters of radioactive materials need only comply with applicable federal regulations.

The state follows federal routing guidelines and recommendations for approving high-level radioactive waste shipment routes. The state's acceptance and approval of NRC-designated routes is the responsibility of the West Virginia Department of Public Safety. The Department also coordinates with the Office of Emergency Services and the Department of Health. However, no formal executive or legislative action has been taken in the state to designate an agency for technical development and policy review concerning routing into and through the state.

The state agency designated by the governor to accpet advance notification and shipment routing information under 10 CFR Parts 71 and 73 is the West Virginia Department of Public Safety. The contact to receive advance notification for spent fuel and large quantity radioactive waste shipments is listed below.

Advance Notification Contact: Col. J. R. Buckalew

Superintendent

Department of Public Safety

725 Jefferson Road

South Charleston, West Virginia 25309

(304) 746-2111 


\section{REFERENCES}

Annual Radioactive Materials Transportation Legal Developments Report. Battelle Project Management Division, Office of Transportation Systems and Planning, Columbus, Ohio. September 1988.

"Governors' Designees Receiving Advance Notification of Transportation of Nuclear Waste." Federal Register. Vol. 53, No. 126. June 30, 1988. pp.24818-24820.

Guidelines for Selecting Preferred Highway Routes for Large Quantity Shipments of Radioactive Materials U.S. Department of Transportation, Research and Special Programs Administration June 1981.

HM-164: Radioactive Materials; Routing and Driver Training Requirements. SAND-85-7160. Sandia National Laboratories. March 1986.

Inconsistency Ruling and Applications under \& 112(a) of the Hazardous Materials Transportation Act. U.S. Department of Transportation, Research and Special Programs Administration. January 5, 1988.

Index to Preemption of State and Local Laws and Regulations under the Hazardous Materials Transportation Act (49 App. U.S.C. 1801 et seq.). U.S. Department of Transportation, Research and Special Programs Administration. January 8, 1988.

Guarterly Radioactive Materials Transportation Legal Developments Report. Battelle Project Management Division, Office of Transportation Systems and Planning, Columbus, Ohio. August 1988.

Southern States Energy Board Legislative Digest 1986. Southern States Energy Board, Atlanta, Georgia. September 1986.

Southern States Energy Board Legislative Digest 1987. Southern States Energy Board, Atlanta, Georgia. October 1987. 
Transportation of Radioactive Materials: A Summary of State and Local Legislative Requirements for the Period Ending December 31, 1985. ORNL/TM-9985. Oak Ridge National Laboratory. April 1986.

"Transportation Routing Issues Related to the Shipment of High-Level Nuclear Waste." OCRWM Backgrounder. DOE/RW-0122. U.S. Department of Energy, Office of Civilian Radioactive Waste Management. January 1987. 

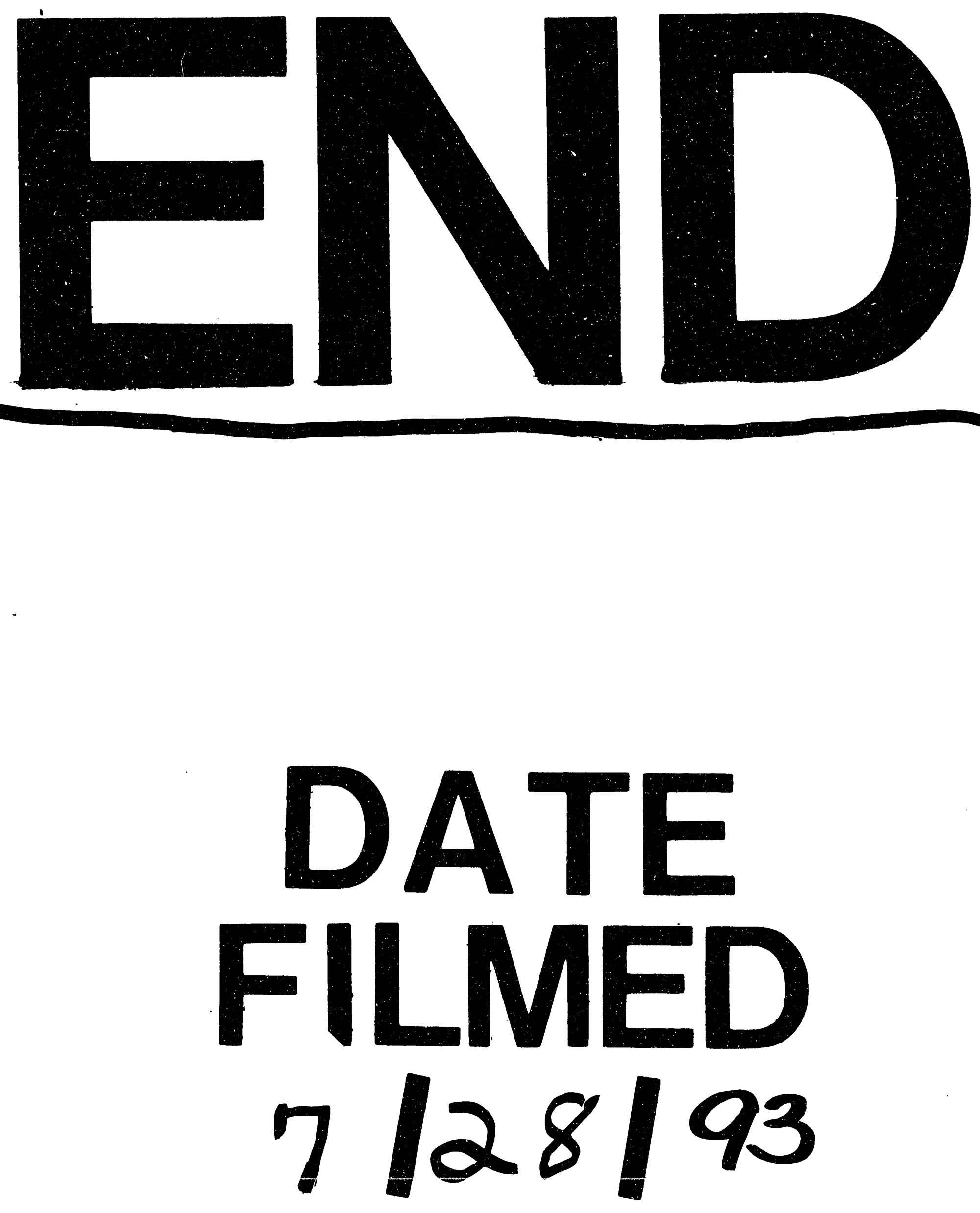
